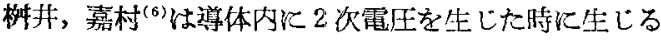
渦流が 1 次側に作用して，1 次側の inductance $L$ を诚 少せしめる結果であり，導体の導電率が良好であれい゙あ

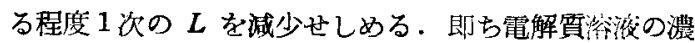
度を高めてゆく時, 初め C (Condenser の capacitance）が優勢的に增してゆくが，まる臨界濃度より・ $L$ (Coil の inductance) の減少が優勢となつて鲍和值に 墶する・従つて

$$
\omega=\frac{1}{\sqrt{L C}} \quad \omega=2 \pi f
$$

より䦌波数は初め诚少するが或極小值より増加し始め， 挮和燵することを推定しているが奏験的証明は全くな されていない，侗両氏その他の测定に於て周波数 10 $30 \mathrm{Mc}$ 飞於ては，乙れら臨界濃度の值として次の㖽を得 ている.著者の Fig. 46 より得大值は次表の最下段に 示す如くである。但し周波数 $22 \mathrm{Mc}, 100 \mathrm{~V}$ 共振回路て 測定したすのである。

\begin{tabular}{l|c|c|c|c}
\hline \hline $\mathrm{HCl}(\mathrm{N})$ & $\mathrm{NaOH}(\mathrm{N})$ & $\mathrm{NaCl}(\mathrm{N})$ & $\mathrm{Mc}$ & 測 是 者 \\
\hline 0.0006 & - & 0.0025 & 5 & 高橋, 林本 ${ }^{(7)}$ \\
0.003 & - & 0.014 & 30 & ${ }^{\prime \prime}$ \\
0.001 & 0.003 & - & $10 \sim 30$ & 栘井, 嘉村 \\
0.00415 & 0.00717 & 0.01585 & 22 & 著 者 \\
\hline
\end{tabular}

(装約)（1）周波数 $22 \mathrm{M} \mathrm{c}\left(C_{1}=50.0\right)$ に同䛾する 回路（同調点 $C_{2}=51.5$ ) て水中に $\mathrm{HCl}, \mathrm{NaOH}, \mathrm{NaCl}$ その他の塩類を滴下する時は濃度が稀薄な間は, それら。 の溶濰の当量伝尊度に比例乙て電流変化を生ずる. 即ち. それらの導電率に応して $\mu \mathrm{A}$ の読みは減少する（但し $\mathrm{mA}$ は導電率に応して堌大寸る).

(2) 辧波数 $22 \mathrm{Mc}\left(C_{1}=50.0\right)$ に同調しない他の適 当な㗢作点 $\left(C_{2}=50.0\right)$ を選んで滴定を行つて (1) もの 場合と同じ関係を持ち，且つ(1)の場合よりる滛汃良: く直線性を示すのでこの点で滴定を行う方がより良好な。 結果が得られる。

(3) $22 \mathrm{Mc}$ の同調回路 $\left(C_{2}=52.0\right)$ で,や〉濃厚な 籁囲につき滴定を行つた時，何れの場合に於ても臨界䟴 度を境として電流変化は反転する．向これらの溶淩の臨 界濃度を求め次の值を得た。

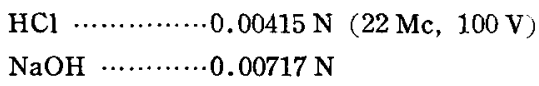

$\mathrm{NaCl} \cdots \cdots \cdots \cdots \cdots, 01585 \mathrm{~N}$ （昭 28-6-23 受理）

交献

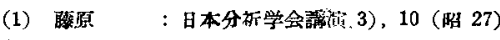

(2) 藤永

(3) James L., Hall: Anal. Chem. 24, 1236 (1952)

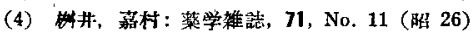

(5) C.N.Reilley, W.H. McCurdy: Anal. Chem. 25, 86 (1953),

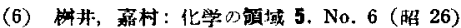

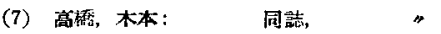

$\checkmark$

\title{
金属チタンの酸化皮膜の化成及静電容量* (チタン電解コンデンサの試み)
}

田岛栄・森 健実

(東京都立大学工学部工業化学教室)

\section{Oxide Film Formation of Metallic Titanium and its Electrostatic Capacity* New Attempt to Prepare Titanium Electrolytic Capacitor}

Sakae TAJIMA and Takemi MORI

(Laboratory of Electrochemistry, Tokyo Metropolitan University, Tokyo)

Titanium electrolytic capacitor ( $T$ ), was studied using commercially pure Ti sheet, and the comparison of $(T)$ was made with aluminium electroly tic capacitor (A).

For the film formation, ammonium borate and especially boric acid proved. to be satisfactory, and the maximum formation voltage is as high as 1300 $\mathrm{V}$ which is very much higher than that of (A), $i$. e., $800 \mathrm{~V}$. The electrostatic capacity of (T) is

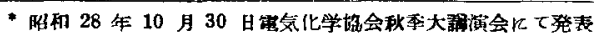

Read before the Fall Meeting of the Society about $8 \sim 40$ times larger than that of (A), the formation voltage being $400 \mathrm{~V}$.

A capacity.with enough stability is obtained by" a capacitor with $\mathrm{Al}$ anode and formed $\mathrm{Ti}$ cathode. Therefore, it seems there exists no polarity in (T). Probably because of the lower grade of $\mathrm{Ti}$ metal, the leakage current and the compensation resistance in the bridge circuit, (the resulting power factor), may be somewhat larger, and the time of formation may be longer. This is slightly improved by eliminating the surface impurities of $\mathrm{Ti}$ sheet 
by preliminary chemical treatment.

Oxide film can be formed also by purely chemical treatment, e.g., by dipping the sheet in a boiling $\mathrm{NaOH}$ solution. By the treatment, a certain amount of capacity is observed, but the leakage current is larger. Hence, the purely chemical tretament will be of no practical use.
The water for the forming electrolyte should be demineralized as in the case of (A). The existence of $\mathrm{Cl}$ ion increases the leakage current.

Titanium electrolytic capacitor is promising because of its excellent electric characteristics, though. there are some defects which need further studies. (Received Jan. 10, 1954)

\section{1. 緒 䔰}

従来コンデンサの誘電体として用いられているアル之 ナ, 酸化チタン,チタン酸バリウムの誘電率はそれそれれ $8 \sim 10,60 \sim 80,1000 \sim 2000$ であるが, 最近金属チタン の登場により, 金属チタン上に電解的又化学的に酸化 チタンの薄膜を化成すれば, 現用のアルミニウム電解コ ンデンサに優る大静電容量, 耐電圧のコンデンサが得ら れるのではないる考光，本研究を行つた．乙の結果は， 容量, 酎圧飞招いてかなり優れた性能を示したが, 䏱洩 電流，力率が稍大なる欠点を示した，その他チタン電解 コンデンサはアルミニウム電解コンデンサに比し喠々の 興味ある性質を走し, 非常に有望であることがわかつ た.

\section{2. 実 験}

使用したチタンは Rem-Cru Titanium Corp. 製の RC-70 工業用純チタン Commercially pure titanium 板で，その品位は 99\%，他に C $0.2 \%$ その他を含み， 現用チタン板としては必ずしも良質とはい兑ない，この ため電解化成の際の漏洩電流が大きく, 力率も大とな る。これを陽極試片とした場合の大さは $40 \times 100 \mathrm{~mm}$ で も $10 \times 10 \mathrm{~mm}$ でも実験結果著しい変化のないことが わかつたので,材料の節約上 $10 \times 10 \mathrm{~mm}$ 截片を用いた.

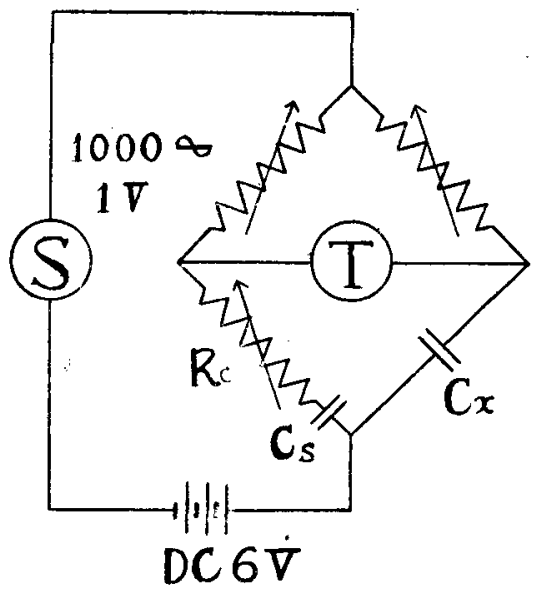

Fig. 1 Measuring Apparatus
容量測定装置 : 横河製インピーダンスブリッヂを用い 自製のオッシレーターとデテクターKよりマイクロアン メーターで平衡を直読した（Fig. 1). 図中 $R_{c}$ は補償 㩐扏で，これは力率と比例関係にある。

コンデンサはペーストを用いて正替に半䩙式のるのる 組立てる代りに，普通略式として測定に用いられている 飽和硼酸アンモン液を電解液とする方法によつた。これ はペーストにより本格的に組立てたすのとはら゙同じ静電 容量を示した。

前処理：チタン片ば先ず Al 䈱の鏡面と対応させるた めにバフで研磨し鏡面としためのを $30 \% \mathrm{Na}_{2} \mathrm{CO}_{3}$ 溶液 の沸滕した中へ約 $2 \mathrm{~min}$ 浸して脱脂し，脱塩水で洗涤 後 $3 \% \mathrm{HNO}_{3}$ に $90 \sim 100^{\circ} \mathrm{C}$ で $5 \mathrm{~min}$ 浸し再び洗涤す Ђ.

化 成：化成用いる水は水道水では不可で，この場 合溜洩電流が多く，化成に長時間を要し，しか子電流は 减少しない，從つてアルミニウム電解コンデンサに颃け ると同じくイオン交換樹脂により $\mathrm{Cl}^{-}$などを除いた瞣 塩水を使用することが必要である。

アルミニウム電解コンデンサの化成に普通に使われる

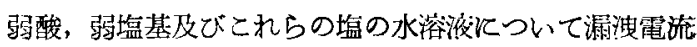
を $1.5 \mathrm{~mA} / \mathrm{cm}^{2}$ 飞保つて定電流法により電在を漸次上 㗤せしめ $5 \mathrm{~h}$ 化成を行つた. 浴澧度, $\mathrm{pH}$, 補償抵抗 $\left(R_{c}\right)$ 静電容量, 化成電圧と時間との関係を Table 1, Fig. 2 に示す。

重 曹 : 陽極表面は化成時間と共に薄灰色より紫色に 変ずるが漏洩電流大きく容量も少い，浴がアルカリ性で あるため波膜が多孔性であるとみられる。

Table 1 Formation with Various Electrolytes,

$1.5 \mathrm{~mA} / \mathrm{cm}^{2}, 5 \mathrm{~h}$

\begin{tabular}{|c|c|c|c|c|c|c|c|}
\hline & Boric & Acid & $\begin{array}{l}\text { Amm. } \\
\text { Borate }\end{array}$ & Borax & $\begin{array}{l}\text { Sodium } \\
\text { Bicarbo- } \\
\text { nate }\end{array}$ & $\begin{array}{l}\text { Tartaric } \\
\text { Acid }\end{array}$ & Amm \\
\hline Conc. & 0.2 & 0.05 & 0.2 & 0.2 & 0.2 & 0.2 & $1 \mathrm{drop}$ \\
\hline $\mathrm{pH}$ & 5.8 & 6.0 & 9.2 & 9.7 & 9.9 & 3.2 & 10.4 \\
\hline$R_{c}(\Omega)$ & $>1100$ & $>1100$ & 800 & 1000 & 900 & 1100 & - \\
\hline $\begin{array}{l}\text { Electrostatic } \\
\text { Capacity }(\mu \mathrm{F})\end{array}$ & 2.6 & 2 & 2.0 & 3.5 & 0.052 & 2.0 & 1.0 \\
\hline $\begin{array}{l}\text { Final Forma- } \\
\text { tion Voltage }\end{array}$ & 251 & & 98 & 116 & 58 & 77 & - \\
\hline
\end{tabular}




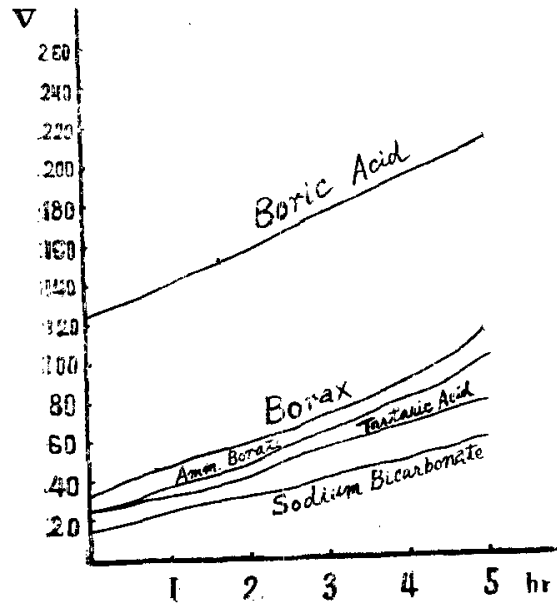

Fig. 2 Formation with Various Electrolytes

啲眇 : 電解化よる酸素ガスが陽極江附着し易く化成が ムラになる、藤色の酸化皮膜を得る。

碽酸アンモン: 紫色の皮膜を生じ補償抵抗 $R_{\theta} 800 \Omega$ で他よりも少く，比較的䌂密な皮膜が得られる。

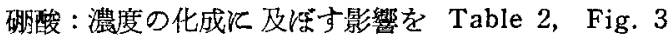

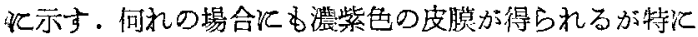
$0.05 \mathrm{~g} / l$ 前後の薄い液で化成電圧の高い皮膜を缹る。

Table 2 Formation with Various Concentration of Boric Acid

\begin{tabular}{c|c|c|c|c}
\hline & $\begin{array}{c}\text { Conc. } \\
(\mathrm{g} / \mathrm{l})\end{array}$ & $\begin{array}{c}\text { Capacity } \\
(\mu \mathrm{F})\end{array}$ & $\begin{array}{c}\text { Compensation } \\
\text { Resistance } \\
R_{c}(\Omega)\end{array}$ & $\begin{array}{l}\text { Final Form- } \\
\text { ation } \\
\text { Voltage (V) }\end{array}$ \\
\hline $\mathrm{A}$ & 0.05 & 2.0 & $>1100$ & 550 \\
$\mathrm{~B}$ & 0.2 & 2.6 & $\prime$ & 215 \\
$\mathrm{C}$ & 0.5 & 3.0 & 1100 & 200 \\
$\mathrm{D}$ & 2.0 & 3.0 & $>1100$ & 150 \\
$\mathrm{E}$ & 5.0 & 3.2 & $"$ & 125 \\
\hline
\end{tabular}

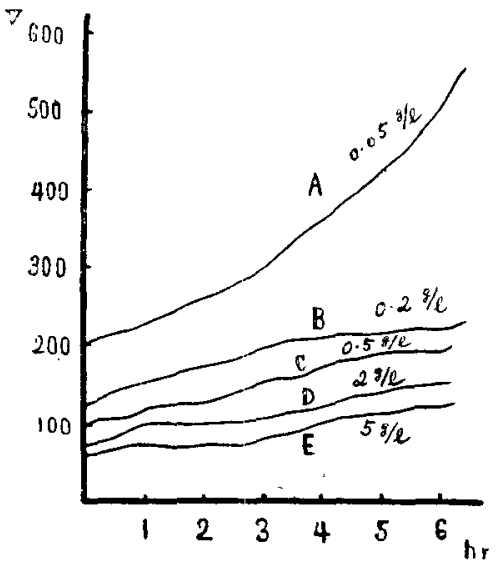

Fig. 3 Formation with Boric Acid

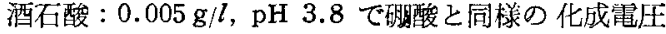
の蔏い酸化皮膛を得るが補償抵抗が稍大きい，種々の酒 石酸濃度に括ける化成状況をTable 3, Fig. 4 亿示す.

Table 3 Formation with Various Concentration of Tartaric Acid

\begin{tabular}{l|c|c|c|c}
\hline \hline & $\begin{array}{c}\text { Conc. } \\
(\mathrm{g} / l)\end{array}$ & $\begin{array}{c}\text { Capacity } \\
(\mu \mathrm{F})\end{array}$ & $\begin{array}{c}\text { Compensation } \\
\text { Resistance } \\
R_{\mathrm{c}}(\Omega)\end{array}$ & $\begin{array}{l}\text { Final Form- } \\
\text { ation } \\
\text { Voltage }(\mathrm{V})\end{array}$ \\
\hline $\mathrm{A}$ & 0.005 & 1.5 & $>1100$ & 270 \\
$\mathrm{~B}$ & 0.02 & 1.8 & $>1100$ & 81 \\
$\mathrm{C}$ & 0.5 & 2.0 & 1100 & 78 \\
$\mathrm{D}$ & 1.0 & 2.0 & $\tau 100$ & 58 \\
$\mathrm{E}$ & 5.0 & 2.0 & 1100 & 36 \\
\hline
\end{tabular}

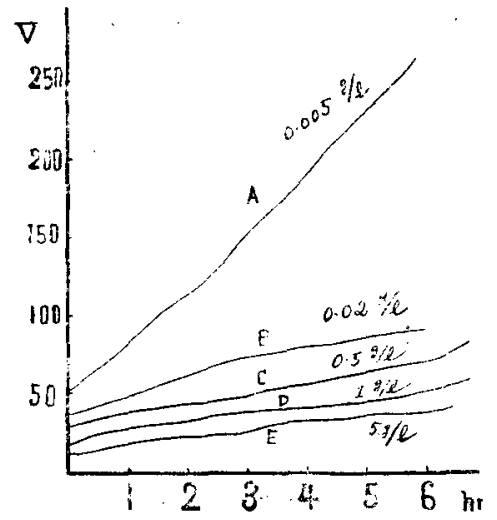

Fig. 4 Formation with Tartaric Acid

その他 $\mathrm{NaCl} 0.2 \mathrm{~g} / l$ 浴では陽極より塩素ガスを発生

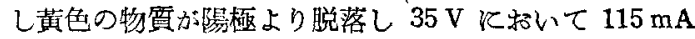
$12 \mathrm{~cm}^{2}$ の漏洩電流が流れ，酸化皮膜の生成は認められ

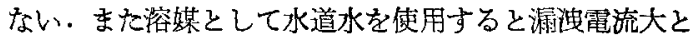
なり，化成時間を長くして子減少しない。即ち $\mathrm{Cl}^{-}$の 存在は化成江有害である。

化成浴江非イオン活性用 Span 80, Nonical 100 を極 く少量 $(0.1 \%$ 溶液を $0.1 \mathrm{cc} / l)$ 添加すると陽極江附着 する気泡の離脱が速かとなり，緶密な皮膜が得られ補償 热抗 $R_{c}$ が $800 \Omega$ 程度に減ずる。

\section{3. アルミニウム電解コンデンサ $と$ 比較}

表面粗面化を施してないプレインの Al 箈を矹酸アン モン渡で $400 \mathrm{~V}$ 化成を行うと， $40 \times 100 \mathrm{~mm}$ の箔の表 敦合計 $80 \mathrm{~cm}^{2}$ でほよ゙ $1 \mu \mathrm{F}$ の静電容量を示すのが一般 である.それ故 $10 \times 10 \mathrm{~mm}$ の簿表衰 $2 \mathrm{~cm}^{2}$ では，0.025 $\mu \mathrm{F}$ 前後の容量を示す䈍である.この值に対してチタン 電解コンデンサを比較したのが Table 4 である.

この表に括いて (1) は通常のアルミニウム電解コンデ 
Table 4 Comparison of Titanium and Aluminum Electrolytic Capacitors

(Formation at $400 \mathrm{~V}, 1.5 \mathrm{~mA} / \mathrm{cm}^{2}$ )

\begin{tabular}{|c|c|c|c|c|c|c|}
\hline & \multirow{2}{*}{$\begin{array}{l}\text { Forming } \\
\text { Condition }\end{array}$} & \multicolumn{3}{|c|}{ Capacitor Construction } & \multirow{2}{*}{ Capacity $(u \mathbf{F})$} & \multirow{2}{*}{$\begin{array}{l}\text { Capacity Mag } \\
\text { nification }\end{array}$} \\
\hline & & Anode & Electrolyte & Cathode & & \\
\hline 1 & $\begin{array}{l}\text { Amm. Bor- } \\
\text { ate, } 400 \mathrm{~V}\end{array}$ & Formed Al & $\begin{array}{l}\text { Satd. Amm. } \\
\text { Borate }\end{array}$ & Al Foil & 0.025 & 1.0 \\
\hline 2 & \multirow{6}{*}{$\begin{array}{l}\text { Boric Acic } \\
0.1 \% \text {, } \\
400 \mathrm{~V}\end{array}$} & Formed Al & $"$ & Al Foil & 0.29 & 12 \\
\hline 3 & & Formed Ti & " & Al Foil & 1.0 & 40 \\
\hline 4 & & Al Foil & " & Formed $\mathrm{Ti}$ & 1.0 & 40 \\
\hline 5 & & Formed Al & " & Formed $\mathrm{Ti}$ & 0.29 & 12 \\
\hline 6 & & Formed $\mathrm{T} i$ & $"$ & Formed Al & Unstable & 一. \\
\hline 7 & & Formed $\mathrm{Ti}$ & Paste & Al Foil & 0.95 & 38 \\
\hline
\end{tabular}

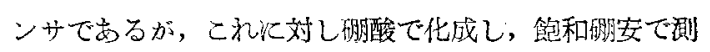
定した（2）が $0.29 \mu \mathrm{F}$ と的 12 倍の窝量を示したこと は偶然の発兒でむる。(3) のチタン電解コンデンサは $1 \mu \mathrm{F}$ て (1) K対し 40 倍，(2) K対しても3 倍骚の静

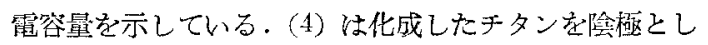
て測定してみたもので，知張り $1 \mu \mathrm{F}$ の安定した静電容 量を示可別を名ると，デタン電解コンデンサには桠性か

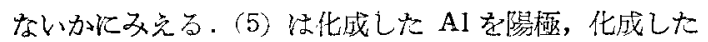
Tiを陰極としたすのて，この場合（4）の結果より容置 が直列にあるものとみなせるから, 全静電容量 $C$ は減 ずる理で, $C=\frac{C_{1} C_{2}}{C_{k}+C_{2}}=\frac{1 \times 0.29}{1+0.29}=0.23 \mu \mathrm{F}$ の球論值

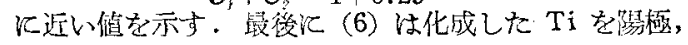

化成した Alを隆極としたもので，この場合容毕は不安

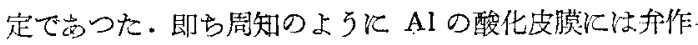
用が出り，乙れを隍極とすることは意味のないことる示 している（7）は半乾式コンデンサ飞使用されている唧 安一グリセリン禿ペース卜を以て実際にチタン電解コン

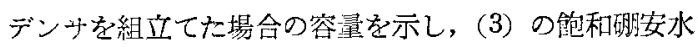
浴液党軍解液とする略式の測定とほざ同一の值を示して いる。

次に硯酸 $0.05 \mathrm{~g} / /$ の淩で $\mathrm{Ti}$ と $\mathrm{Al}$ を同一条件で $150 \mathrm{~V}$ 范化成した際の静電容量, 補儥抵抗, 倍率を. Table 5 r示す.

Table 5 Comparison of Titanium and Alminum Elelerolytic Capacitors

(Formation at $150 \mathrm{~V}, 1.5 \mathrm{~mA} / \mathrm{cm}^{2}$ )

\begin{tabular}{|c|c|c|c|c|c|c|c|}
\hline & \multirow{2}{*}{$\begin{array}{l}\text { Forming } \\
\text { Condition }\end{array}$} & \multicolumn{3}{|c|}{ Capacitor Construction } & \multirow{2}{*}{$\begin{array}{l}\text { Capacity } \\
(\mu \mathrm{F})\end{array}$} & \multirow{2}{*}{$\begin{array}{l}\text { Capacity } \\
\text { Magnification }\end{array}$} & \multirow{2}{*}{$\begin{array}{l}\text { Compensation } \\
\text { Resistance } R_{o}(\Omega)\end{array}$} \\
\hline & & Anode & Electrolyte & Cathode & & & \\
\hline 1 & Boric Acid & Formed Al & $\begin{array}{l}\text { Satd. Amm. } \\
\text { Borate }\end{array}$ & Al Foil & 0.24 & 1.0 & 300 \\
\hline 2 & $0.05 \mathrm{~g} / \mathrm{l}$ & Formed $\mathrm{Ti}$ & $"$ & Al Foil & 3.4 & 14.2 & 1100 \\
\hline 3 & $150 \mathrm{~V}$ & Formed Al & $"$ & Formed $\mathrm{Ti}$ & 0.23 & 0.96 & 240 \\
\hline
\end{tabular}

(1) のアルミニウム電解コンデンサに比し（2）のチ タン霓解コンデンサは 14.2 倍の静電容量を示し，(3) の化成 $\mathrm{Al}$ 党陽極, 化成 Ti を除極とするコンデンサは Table 2 飞拔けると同じく，容量が直列に 2 個入ること そなり，0.23 $\mu \mathrm{F}$ て，(1)，(2)の結果より得られる理論 值 $C=\frac{C_{1} C_{2}}{C_{1}+C_{2}}=\frac{0.24 \times 3.4}{0.23+3.4}=0.224 \mu \mathrm{F}$ と綺覆な一致 をみせている・直列に組合せた場合容量はこのよ5亿減 じているが，補信抵抗は著しく減して括り，従つて力率 る減じていることがわかる、またこの結果から，チタン 電解コンデンサは極性学示さないような結果となつてい、 乃.

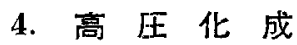

䃆酸 $0.05 \mathrm{~g} / l$ を化成淁上し， $5 \mathrm{~mA} / \mathrm{cm}^{2}$ の定電流化 成で 4〜5h にして $1300 \mathrm{~V}$ 耐圧の皮脱を得た。これを

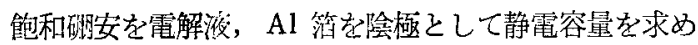
た所, 約 $1 \mu \mathrm{F}$ を示し, $400 \mathrm{~V}$ 化成のすのと容量化変化 がなかつた、これはアルミニウム電解コンデンサK括け る通則と反方る。

\section{5. 化学化成}

チタンに対しては䉓解によらない純化学処理でも酸化 皮膜を化成し得ると考充，2,3 の実験を行つた。 
先ずクロム硫酸混湾（重ク口ム酸力リ $50 \mathrm{~g}$, 硫酸 50 cc, 水 $1 l$ ) の沸灙浴中で $10 \mathrm{~min}$ 浸漬したが，容量を 示主程の酸化皮蓦は化成されなかつた。
苟性ソーダ浴中で煮进すると皮荧が形成され，コンデ ンサとして静電容量を示した。但し酎電圧は調べなかつ た. 化成液濃度を容量との関係を Table 6 に示与.

Table 6 Chemical Formation with $\mathrm{NaOH}$

\begin{tabular}{c|c|c|c|c|c|c}
\hline & $\begin{array}{c}\text { NaOH conc. } \\
(\mathrm{g} / \mathrm{l})\end{array}$ & $\begin{array}{l}\text { Time of } \\
\text { Boiling(min.) }\end{array}$ & Temp. $\left({ }^{\circ} \mathrm{C}\right)$ & $\begin{array}{l}\text { Appearance } \\
\text { of Surface }\end{array}$ & $\begin{array}{l}\text { Compensation } \\
\text { Resistance } R_{c}(\Omega)\end{array}$ & Capacity \\
\hline 1 & 8 & 30 & $99 \sim 100$ & no change & 0 & 0 \\
2 & 20 & $"$ & $100 \sim 101$ & yellowish-brown & $>1100$ & 3.8 \\
3 & 70 & 103 & violet & $>1100$ & 4 \\
4 & 300 & 110 & violet $\rightarrow$ gray & $>1100$ & 5 \\
\hline
\end{tabular}

またガスバーナーの酸化焰の中で赤熟しても表面は襣 色の皮膜に覆われ，静電容量 $0.238 \mu \mathrm{F}, R_{c} 200 \Omega$ を示 した.

以上の化学化成による皮膛は瀮洩電流大で実際には使 用は困難かと思就る。

\section{6. 漏渑電流について}

上钎の諸法によつて得たジタンの化成皮胡は何れも湭 洩電流，補僋抵抗（従つて力率）がアルミニウム䨘解コ ンデンサに比べて大である。これは試料のチタンの純度 が高くないことが大きな理旺であると考えられる。前記 のよ5に化成淮に界面活性剂の添加るこれを減ず万のに 効果があつたが，更にチタン試片を化成前に $6 \mathrm{~N} \mathrm{HC}$ K $5 \mathrm{~h}$ 浸清して後, $0.05 \mathrm{~g} / l$ 碵酸浴で化成すると補償

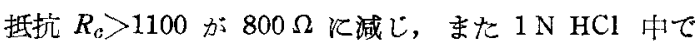
陽極として $2 \mathrm{~V}, 10 \mathrm{~min}$. 電解したものは $R_{c} 600 \Omega$ K まで低下した。これは Ti 中の不純物が表面的にある程 度除かれた」めをみられる。

また電解化成後, クロム酸の沸滕淩中へ浸したり，ア

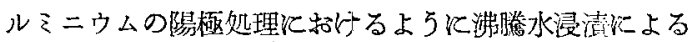
封孔効果を調べてみたが，何れ本效果がなかつた。

\section{7. 結 言}

金属チタンが製造されるよ 5飞なりたので, 従来のア ルミニウム電解コンデンサに代るチタン電解コンデンサ を試作して文たが，400 V 同一条件の化成，コンデンサ 構成化括いて，チタン電解コンデンサはアルミニウム電 解コンデンサに比し 12〜40 倍の静電容量を示し, また $1300 \mathrm{~V}$ の化成にも耐えたが, 漏洩電流, 力率が大きい 欠点があつた．これはチタンの純度が関係しているるの とみられる。またコンデンサ構成に和いて化成チタンを 陰極としてる安定した静電容量が発現するつで, チタン 霓解コンデンサではアルミニウム電解コンデンサと異り 極性を有しない上5にも思われるが，金属チタン上に化 学的に酸化皮膜を生ぜしめ，これを若干水素還元したも
のか $100 \sim 150^{\circ} \mathrm{C}$ で酸化チタン整流器として働くとい5 最近の報告(1)あおり，これを和か断定することはで きない，然しながら本研究で明かになつたよらにチタン 電解コンデンサはすぐれた性質を有して呿り甚坊有望で ある。

\section{8. 摘 要}

（1） RC-70 工業用純チタン板を用いてチタン電解 コンデンサを試作しアルミニウム霆解コンデンサと比較 した。

(2) 化成江は嗍安特に硼酸がよく $1300 \mathrm{~V}$ 化成を行 らことができた。これは Al の最高 $800 \mathrm{~V}$ 化成に比し 著しく高い。

（3）静電容量は AI 簿を陰極として，アルミニウム 電解コンデンサに比し $400 \mathrm{~V}$ 化成注いて 8〜 40 倍の 倠を示した。

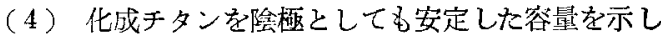
たから，チタン霞解コンデンサは一見極性を示さないか 淡觉る。

(5) 試料の純度の関係で漏洩電流, 補信抵抗(力率) が大きく，化成時間が長い欠点がある。乙れは改善され よう.例え洼適当な化学的前処理で表面不純物を除くこ とにさり若干改善された。

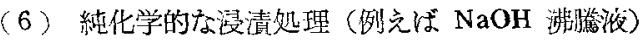
によりても皮膜を生し，容量を生じたが，漏洩電流が大 きく，現状では来用にならない。

(7) 化成に用いる溶桇は脱㙁水でなければならな い. $\mathrm{Cl}^{-}$の存在は漏洩電流を大炕す。

本湖究を行5飞当り，チタン誈料は米国 Rem-Cru Titanium Corp.より提供を受けた。附記して深甚の謝 意を表する。

(炤 29.1.10 受理)

文 献

(1) R.G. Breckenridge, W.R. Hosler: J. Research 'Natl. Bur. Stds., 49, 65 72 (1952) (Research paper No. 2344) 